\title{
Mass Transfer Studies with Submerged Impinging Jets in Closed Cylindrical Electrolytic Cell in the Presence of Solids
}

\author{
S. Feroz ${ }^{* 1}$, B.V.L. Rao², C. Bhaskarasarma ${ }^{3}$ and V.S.R.K. Prasad ${ }^{3}$ \\ 1 Department of M\&IE, Caledonian College of Engineering, Sultanate of Oman \\ 2 Department of Chemical Engineering, Govt. Polytechnic College, Visakhapatanam 530 012, India \\ ${ }^{3}$ Department of Chemical Engineering, Andhra University, Visakhapatanam 530 003, India
}

Received 26 August 2006; accepted 11 February 2007

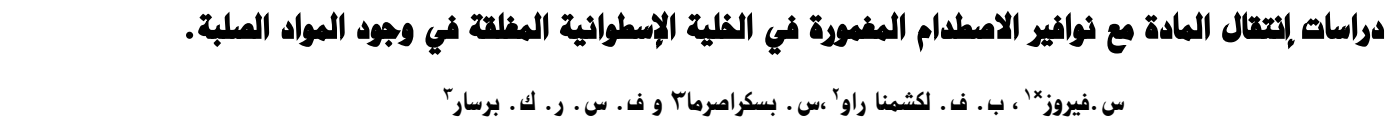

الفلامة: دراسة مختبرية تتناول انتقال المادة في الكتروليت تدفق السائل الحملي القسري من خلال النافورة الهغمورة الهمطدمة بسطح دائرى لذلية اسطوانية مغلقة في وجود

الهواد الصلبة (خزف الخرز). ان البتفيرات الفعالة والهندسية ذات الصلة بهذه الدراسة تشهل معدل التدفق ، قطر فوهة الأنبوب، ارتفاع فوهة الإنبوب من سطح الهدف، ونسبة

الهواد الصلبة. ان قياسات انتقال الهادة، التي أجريت بالطريقة الكهروكيميائية، تقترح علاقات تجريبية بهناطق اصطدام ونقص البعامل.

الهزداه الهنتامية: منطقة الاصطدام، منطقة تناقص المعامل ، معامل انتقال البادة، السطح الحلقى البستهدف.

\begin{abstract}
An experimental study of mass transfer in forced convective flow of fluid electrolyte through submerged jets impinging normal to the target surface in a closed cylindrical cell in the presence of solids (Porcelain beads) is reported. The pertinent dynamic and geometric variables of this study are flow rate, diameter of the nozzle, height of the nozzle from the target surface and solids fraction. The mass transfer measurements, made by the electrochemical method propose empirical correlations in the impingement and decreasing coefficient regions.
\end{abstract}

Keywords: Impingement region, Decreasing coefficient region, Mass transfer coefficient, Target surface

\section{Notation}

Cf Correlation factor

$D_{c} \quad$ Diameter of the cell, $\mathrm{m}$

$d_{p} \quad$ Diameter of solids, $\mathrm{m}$

$d_{j} \quad$ Diameter of the nozzle, $\mathrm{m}$

$E_{1} t_{0} E_{7} \quad$ Electrodes on target surface

$h \quad$ Height of the nozzle from target surface, $m$

$J_{D} \quad$ Mass transfer factor

$k_{L} \quad$ Mass transfer coefficient, $\mathrm{m} / \mathrm{s}$

$N_{R e} \quad$ Reynolds number $\frac{\mathrm{vd}_{\mathrm{j}} \rho}{\mu}$

$\chi \quad$ Solids fraction

$x \quad$ Average radial distance of electrode from the target surface, $\mathrm{m}$

$v \quad$ Velocity of fluid electrolyte from the nozzle, $\mathrm{m} / \mathrm{s}$

\section{Introduction}

In industrial operations, various augmentation techniques are in practice, which reduce equipment sizes and increase out-puts without impairing the efficiency of pro duction. Impinging jet systems have been well established as an effective technique for heating, cooling, or drying a target surface and have a variety of industrial applications, including the tampering of glass, the drying of film and textile, and the cooling of hot steel plate and gas turbine cascade. Recently, the jet impingement has also been used for the cooling of microelectronic components. Literature reveals several investigations (Gardon and Cobonpue, 1962; Gardon and Akfirat, 1965; Korger and Krizek, 1966; Subba Rao et al. 1973; Coeuret, 1975; Chin and Tsang, 1978; Chang et al. 1995, Kendoush, 1998; Lee et al. 2002; Travnicek and Tesar, 2003) on heat/mass transfer using jets in open and closed containers. However, studies on the effect of submerged impinging jets in closed cylindrical cell in the presence of solids are meager. The presence of solids provides a large surface of contact and causes rapid removal of heat in electro-chemical processes such as electrochemical surface treatment of selective area, annealing of metals and plastic sheets. The present study is directed towards the investigations on mass transfer with impinging submerged jets in closed cylindrical cell in the presence of solids and correlation of data in impingement and decreasing coefficient regions. 


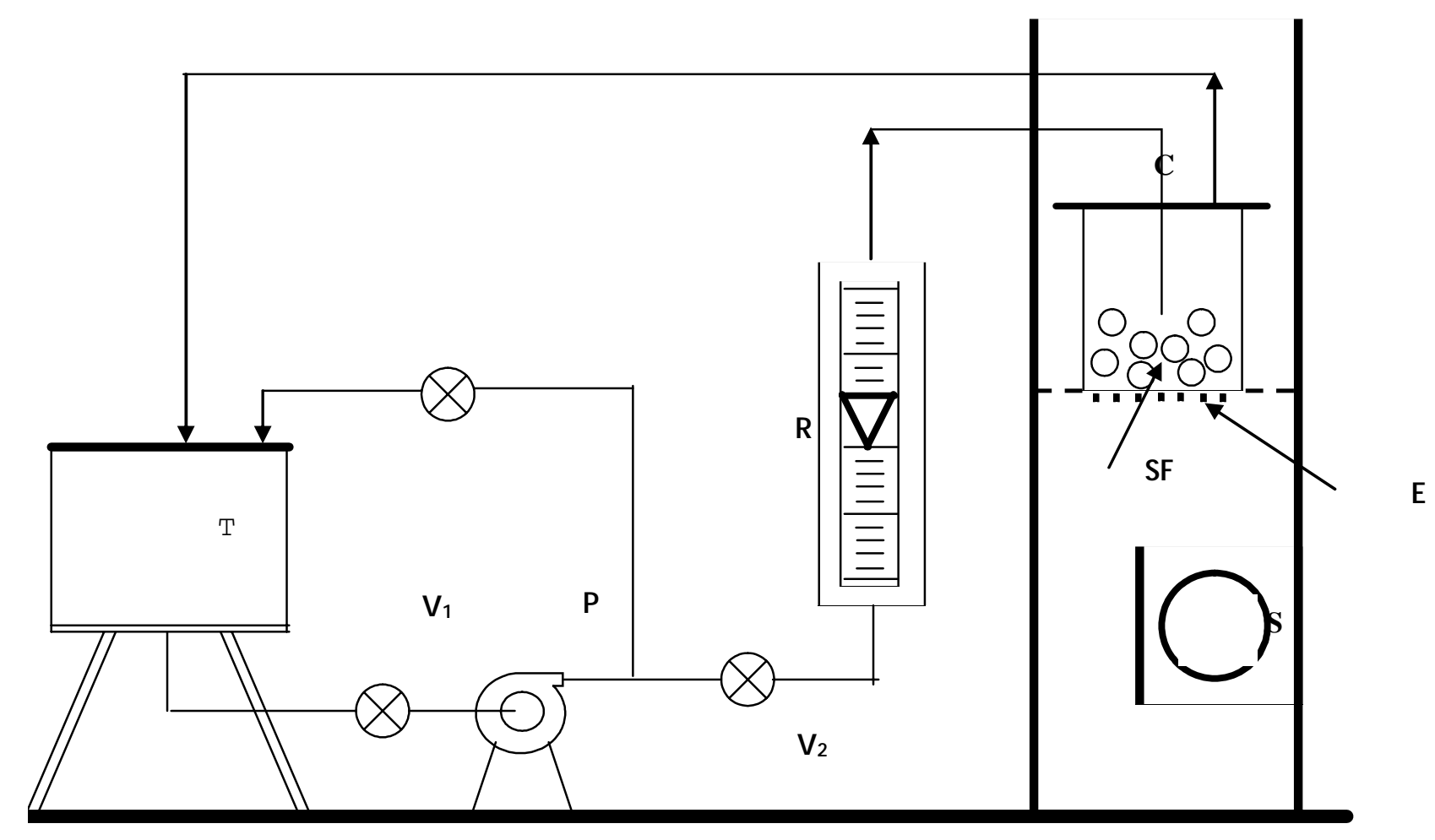

Figure 1. Schematic diagram of experimental set-up

\section{Experimental Set-up and Procedure}

An electrolytic cell of $0.1475 \mathrm{~m}$ diameter and $0.173 \mathrm{~m}$ height fabricated with PVC has been employed for studying the effects of various parameters. A schematic diagram of the apparatus is shown in Fig. 1.

The set-up mainly consists of a storage tank (T), a pump (P), a rotameter $R$, an electrolytic cell $(C)$, and a selector switch $(S)$. The storage tank is made of a copper sheet with a capacity of about $0.150 \mathrm{~m} 3$ and is provided with a drain valve $\left(V_{1}\right)$ at the bottom. The outlet line at the bottom of the tank is connected to the suction side of the pump and in between a valve $\left(V_{2}\right)$ was provided to isolate the pump from the storage tank whenever necessary. A $0.746 \mathrm{~kW}$ motor is used to drive the pump, which circulates the electrolyte solution. The outlet from the pump is divided into two lines - one for direct entry of electrolyte into the cell through a rotameter and the other to serve as a by-pass which returned to the storage tank, the by-pass being controlled by valve $\left(V_{3}\right)$. Three convergent nozzles of diameters $0.002112 \mathrm{~m}, 0.005623 \mathrm{~m}$ and $0.007831 \mathrm{~m}$ were fabricated using copper tube. Nozzle is provided with a screw threading to fit with the inlet tube. A rotameter of Fischer and Porter make, with a metering range of 0 - $3.33 \times 10^{-4} \mathrm{~m}^{3} / \mathrm{s}$ has been used to measure the electrolyte flow rate.

The cell is fixed between two circular hylam plates of the same dimensions. The top plate is provided with two holes, one for the insertion of nozzle and the other for exiting the electrolyte and returning to the electrolyte stor- age tank. Copper tubes are provided as inlet and outlet for the electrolyte. The bottom plate served as "Target surface". Concentric ring electrodes $\left(E_{2}\right.$ to $\left.E_{7}\right)$ are cut out of copper sheet of $0.00125 \mathrm{~m}$ thick and fixed at equidistant ie. $0.01 \mathrm{~m}$ apart, flush with the inside surface. The central electrode $\left(E_{1}\right)$ is a small disc cut out of a copper rod of $0.02 \mathrm{~m}$ diameter, fixed at center point of the target plate where the jet impinges. All electrodes are provided with copper terminals for making electrical connections. The inlet copper tube served as the counter electrode. The electrolytic cell is charged with varying quantities of solids (SF) ( $0.5 \%$ to $3 \%$ of total volume), which are a mixture of spherical and cylindrical shaped porcelain beads of $0.005 \mathrm{~m}$ diameter and $0.008 \mathrm{~m}$ length with a bulk density of $1200 \mathrm{~kg} / \mathrm{m}^{3}$ and true density of $1267 \mathrm{~kg} / \mathrm{m}^{3}$. Nozzles of three different sizes $0.007831 \mathrm{~m}, 0.005623 \mathrm{~m}$ and $0.002112 \mathrm{~m}$ are used to generate the impinging jet flow. Limiting currents are measured for reduction of ferri-cyanide ion, once the flow rate and temperature was stabilized. The electrochemical procedure adopted for the measurement is same as described in the earlier studies (Lin et al. 1951; Sakakihara et al. 1994; Subba Rao et al. 1973). An electric potential was applied in steps across the test and counter electrode and the corresponding currents were noted. The attainment of limiting current was observed by a sharp rise in potential for a small increase in current. The electrolyte consisted of equi-molal solutions of $(0.01 \mathrm{M})$ of potassium ferricyanide and potassium ferrocyanide with an excess indifferent electrolyte $0.5 \mathrm{~N}$ sodium hydroxide. Measurements of limiting currents are obtained at different flow rates. For any individual run the 
temperature remained constant within $\pm 0.1{ }^{0} \mathrm{C}$ and if the temperature varied more than $\pm 0.1{ }^{0} \mathrm{C}$, the run was discarded. The electrolyte was analyzed for each and every run and the reproducibility of data was tested from time to time by repeating one of the previous runs under identical conditions. The diameters of nozzles, height of the nozzle from the target surface and solid fraction are varied and experiments are repeated for each case. The ranges of varia bles covered are given in Table 1.

Table 1. Ranges of variables covered in the present day

\begin{tabular}{|c|c|c|c|}
\hline S.No & Variable & Minimum & Maximum \\
\hline 1. & $\begin{array}{l}\text { Flow rate }\left(Q \times 10^{5}\right) \text {, } \\
\mathrm{m}^{3} / \mathrm{s}\end{array}$ & 3.4 & 14.0 \\
\hline 2. & Velocity $(v), \mathrm{m} / \mathrm{s}$ & 0.705 & 40.0 \\
\hline 3. & $\begin{array}{l}\text { Height of the } \\
\text { nozzle from the } \\
\text { target surface, } \\
\left(h \times 10^{2}\right), \mathrm{m}\end{array}$ & 1.0 & 8.0 \\
\hline 4. & $\begin{array}{l}\text { Diameter of the } \\
\text { nozzle, } \\
\left(d j \times 10^{2}\right), \mathrm{m}\end{array}$ & 0.2112 & 0.7831 \\
\hline 5. & $\begin{array}{l}\text { Average radial } \\
\text { distance of the } \\
\text { electrode on the } \\
\text { target surface from } \\
\text { the center, }\left(x^{*} 10^{2}\right) \text {, } \\
\mathrm{m}\end{array}$ & 0.0 & 6.328 \\
\hline 8. & $\begin{array}{l}\text { Reynolds number, } \\
N_{R e}\end{array}$ & 6707 & 102405 \\
\hline 9. & $\begin{array}{l}\text { Schmidt number, } \\
\text { Sc }\end{array}$ & 698.6 & 931.9 \\
\hline
\end{tabular}

\section{Results and Discussion}

The hydrodynamics of the impinging jet flow may be visualized (Gardon and Cobonpue, 1962; Gardon and Akfirat, 1965; Korger and Krizek, 1966; Subba et al. 1973; Coeuret, 1975; Chin and Tsang, 1978) as the jet issuing from the nozzle onto the target surface, gradually flows away radially towards the outer edge of the target surface or the confining wall of the electrolyte cell depending upon whether it is free jet or submerged jet. In the presence of solids in closed cells with submerged impinging jets, the flow patterns are complex for any mathematical treatment and hence an experimental modeling has been attempted by the empirical method. The plot of mass transfer coefficients $\left(k_{L}\right)$ (calculated from the limiting current density, similar to earlier studies) (Lin et al. 1951; Sakakihara et al. 1994; Subba et al. 1973) for the reduction of ferricyanide ion is drawn against the dimensionless distance ' $x / D_{c}$ ', where ' $x$ ' is the average radial distance of the ring electrodes from the center of the cell and is shown in Fig. 2. A close inspection of the trends in these plots shows the existence of the following regions due to different flow patterns: (1) Impingement region - wherein the limiting current densities are comparatively very high which can also be referred to as stagnation zone. (2) Transition region - wherein the limiting current densities decrease with the radial distance of the electrode. (3) Wall jet region - wherein the limiting current densities decrease relatively very slowly as compared to those in the transition region. The change from region 2 to region 3 is not abrupt but smooth, hence these two region ie. transition and wall jet region are therefore combined to form a "decreasing coefficient region". It is also observed that only central electrode $\left(x / D_{c}=0\right)$ falls into the impingement region.

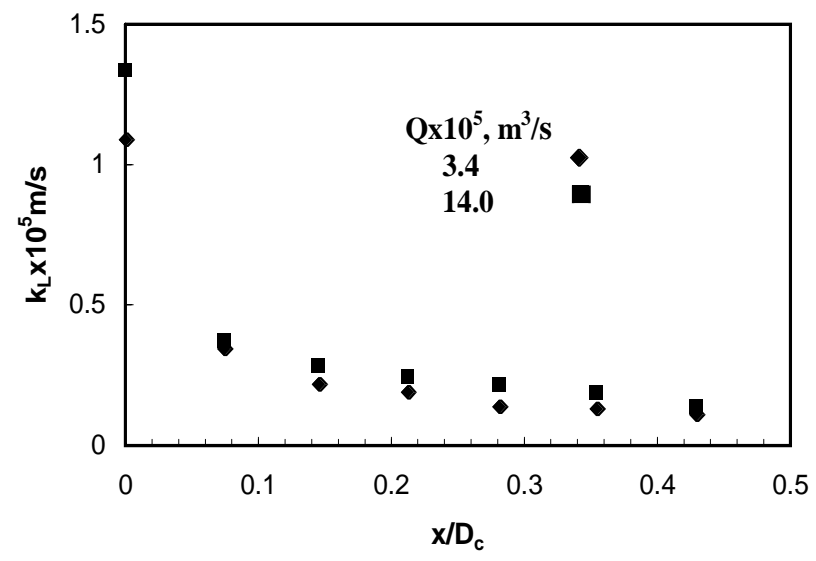

Figure 2. Variation of mass transfer coefficients with $\mathrm{x} / \mathrm{D}_{\mathrm{c}}\left(\mathrm{d}_{\mathrm{p}}: 5 \times 10^{-3} \mathrm{~m}, \lambda: 0.01, \mathrm{~d}_{\mathrm{j}}: 0.7831 \times 10^{-2}\right.$ $\mathrm{m}, \mathrm{h}: 2.5 \times 10^{-2} \mathrm{~m}$ )

\subsection{Effect of Flow Rate on Mass Transfer Coefficients}

The mass transfer coefficient data of $E_{1}, E_{3}$ and $E_{7}$ are plotted against the flow rates as shown in the Fig. 3. It has been found that the values of $k_{L}$ increase gradually with an increase in the flow rate, due to high turbulence on the target surface both in the case of impingement $\left(E_{1}\right)$ and decreasing coefficient regions $\left(E_{3}\right.$ and $\left.E_{7}\right)$.

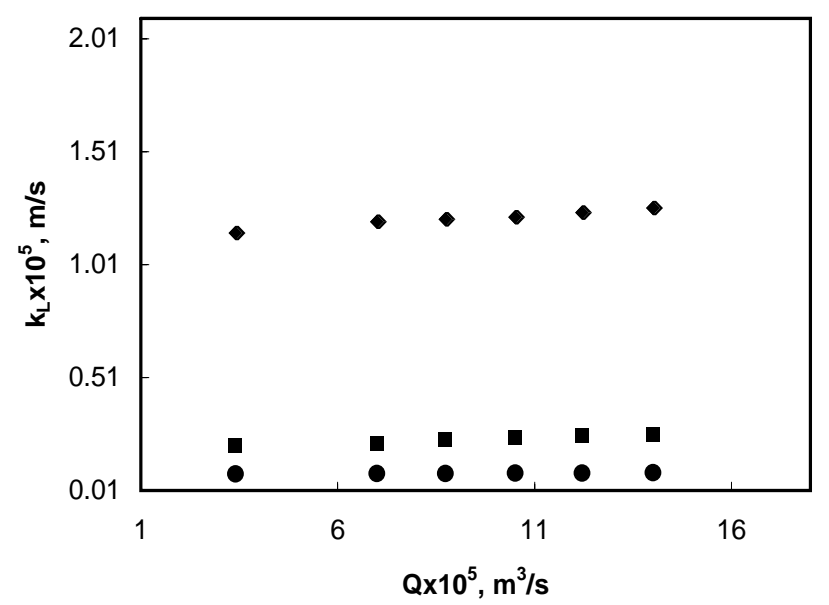

Figure 3. Variation of mass transfer coefficients with flow rates $\left(d_{\mathrm{p}}: 5 \times 10^{-3} \mathrm{~m}, \lambda: 0.01, d_{\mathrm{j}}: 0.5623\right.$ $\left.x 10^{-2} \mathrm{~m}, \mathrm{~h}: 2.5 \times 10^{-2} \mathrm{~m}\right)$ 


\subsection{The Effect of Height of Nozzle from Target Surface on Mass Transfer Coefficients}

The effect of nozzle height from the target surface on the mass transfer coefficients is shown in Figs. 4a and $4 \mathrm{~b}$ for three different heights covered in the present study ie. $0.01 \mathrm{~m}, 0.04 \mathrm{~m}$ and $0.08 \mathrm{~m}$. It has been found that with an increase in the height of the nozzle from the target surface, the values of the mass transfer coefficient decreases. The variation of mass transfer coefficients with nozzle height is found to be marginal in both impingement $\left(E_{1}\right)$ and decreasing coefficient regions $\left(E_{7}\right)$, as shown in Figs. 4a and $4 \mathrm{~b}$, respectively. As the height increases the liquid jets that emerge out from the nozzle are loosing the impact of their momentum and not fully reach the target surface where the mass transfer occurs. Similar observations were reported in earlier studies on single, open free and submerged jets (Gardon and Cobonpue, 1962; Gardon and Akfirat, 1965; Korger and Krizek, 1966; Subba et al. 1973; Coeuret, 1975).

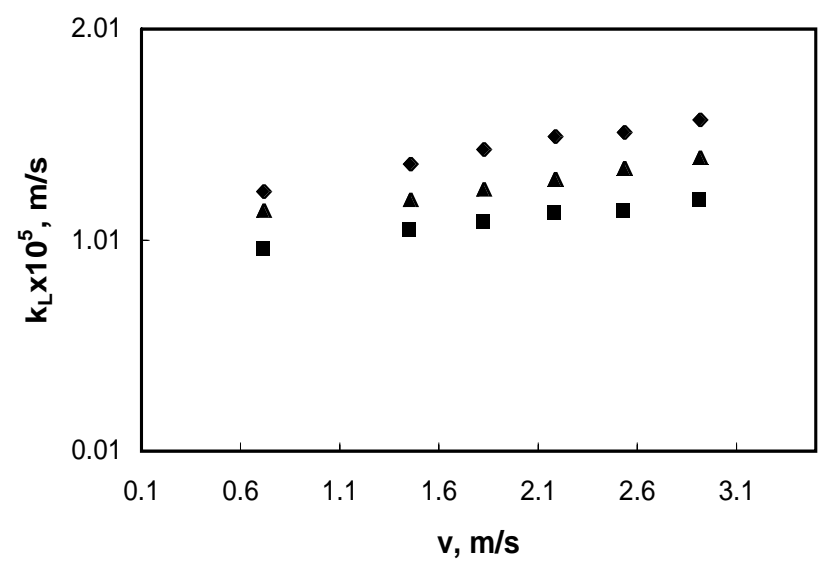

Figure 4a. Variation of mass transfer coefficients with velocity for different heights of nozzle from target surface in impingement region $\left(E_{1}, d_{p}: 5 \times 10^{-3} \mathrm{~m}, \chi\right.$ $\left.: 0.01, d_{j}: 0.21120 \times 10^{-2} \mathrm{~m}\right)$

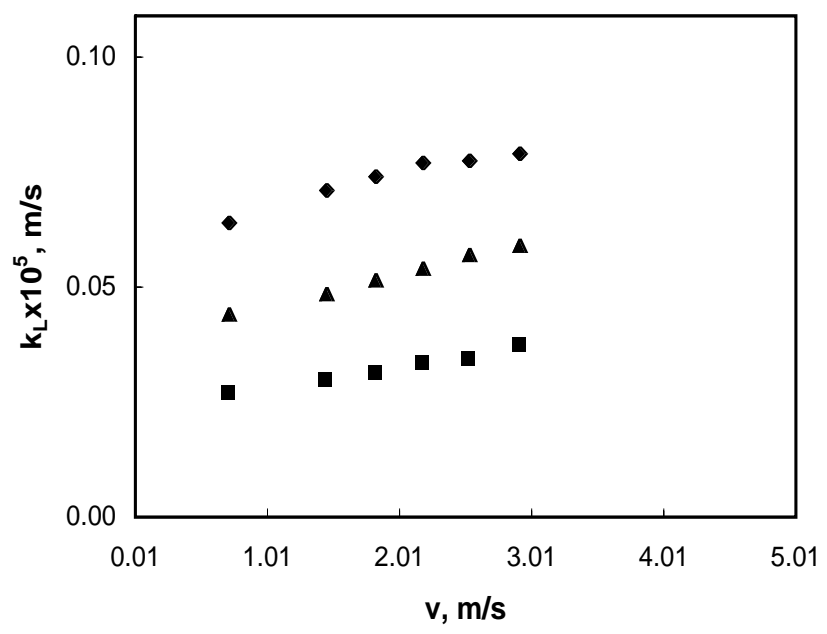

Figure 4b. Variation of mass transfer coefficients with velocity for different heights of nozzle from target surface in decreasing coefficient region $\left(E_{7}, d_{p}: 5 \times 10^{-3} \mathrm{~m}, \chi\right.$ : $\left.0.01, d_{i}: 0.21120 \times 10^{-2} \mathrm{~m}\right)$

\subsection{The Effect of Nozzle Diameter on Mass Transfer Coefficients}

The values of mass transfer coefficients of $E_{1}$ and $E_{7}$ are plotted against velocity for three different nozzle diameters keeping other parameters constant as shown in Figs. 5a and 5b. It has been found that in both regions $k L$ increases with an increase in the nozzle diameter for a given velocity due to large scale eddy turbulence on the target surface.

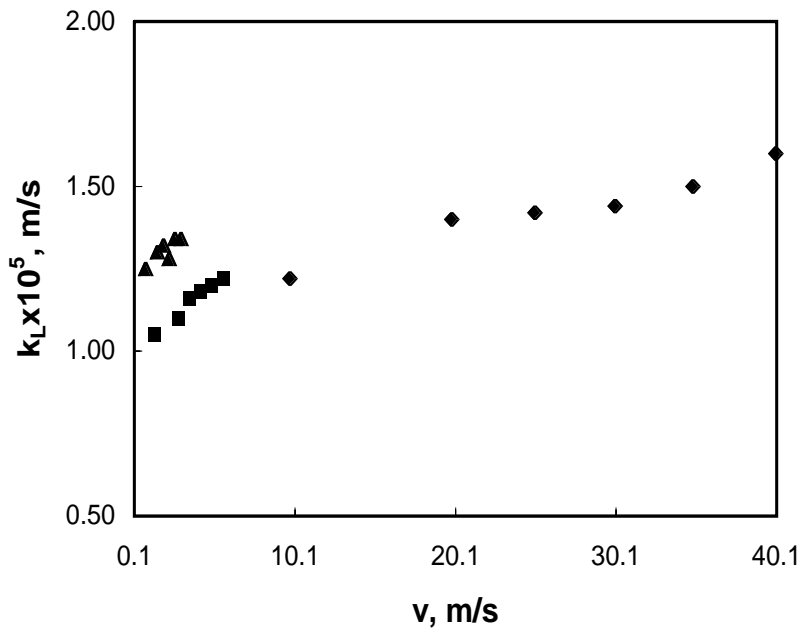

Figure 5a. Variation of mass transfer coefficients with velocity for different nozzle diameters in impingement region ( $E_{1}$, $\left.d_{p}: 5 \times 10^{-3} \mathrm{~m}, \chi: 0.01, h: 2.5 \times 10^{-2} \mathrm{~m}\right)$.

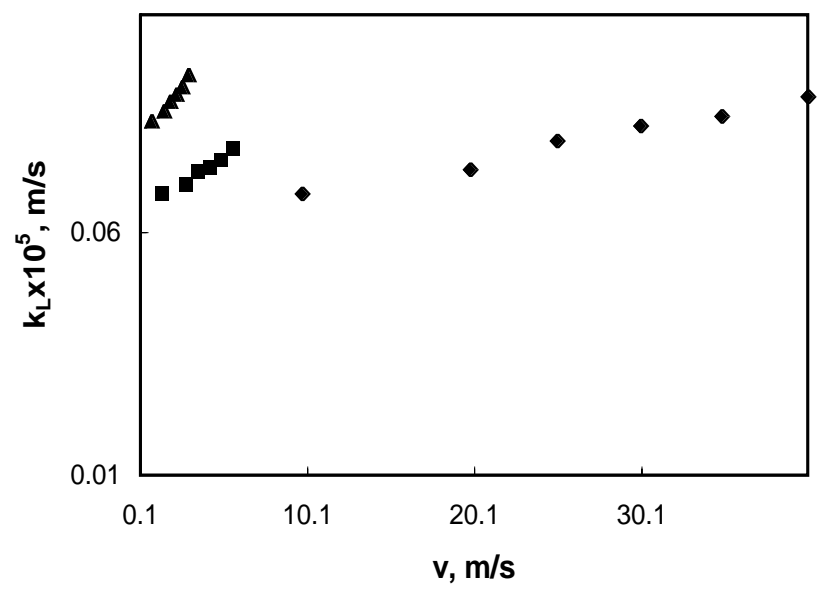

Figure 5b. Variation of mass transfer coefficient s with velocity for different nozzle diameters in decreasing coefficient region $\left(E_{7}, d_{p}: 5 \times 10^{-3} \mathrm{~m}, \chi: 0.01, h\right.$ : $\left.2.5 \times 10^{-2} \mathrm{~m}\right)$

\subsection{The Effect of Solids on Mass Transfer Coefficients}

The variation in the mass transfer coefficients of $E_{1}$ and $E_{7}$ with the percentage of solids presence is shown in Figs. $6 \mathrm{a}$ and $6 \mathrm{~b}$. The percentage of solids varied from $0.5 \%$ to $3 \%$ of volume of the cell. Mass transfer coefficients are found to increase marginally with the increase in solids up to $1 \%$ and then decreases in both impingement 
and decreasing coefficient regions. It has been observed that at a lower solid fraction the scouring action together with the hydrodynamic turbulence increased the mass transfer coefficients marginally. At a higher solid fraction, the effect of solids is found to decrease gradually resulting in lower coefficients.

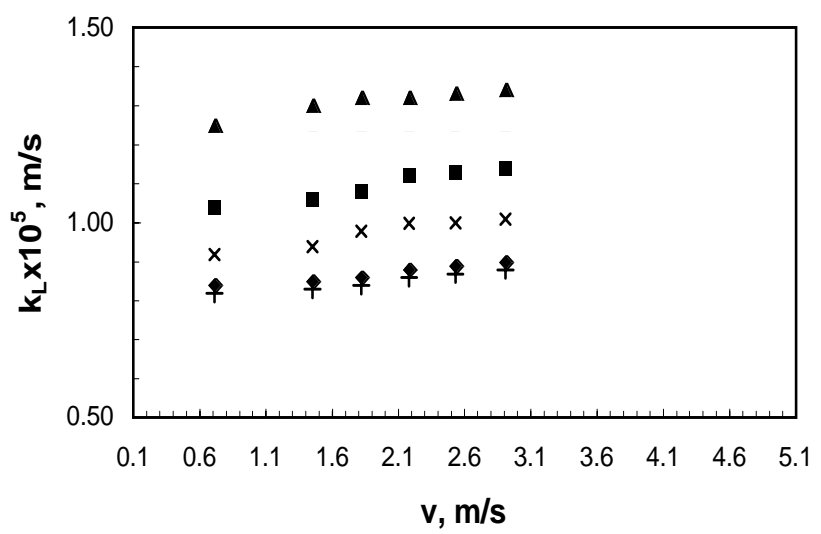

Figure 6a. Variation of mass transfer coefficients with velocity for different solids fraction in impingement region $\left(E_{1} d_{p}: 5 \times 10^{-3} \mathrm{~m}, d j\right.$ : $\left.0.7831 \times 10^{-2} \mathrm{~m}, \boldsymbol{h}: 2.5 \times 10^{-2} \mathrm{~m}\right)$

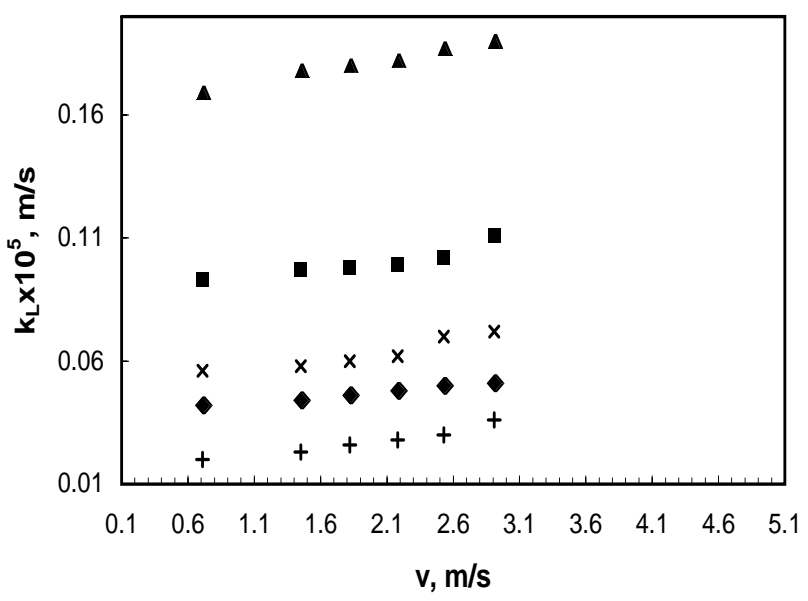

Figure 6b. Variation of mass transfer coefficients with velocity for different solids in decreasing coefficient region $\left(E_{7} d_{p}\right.$ : $5 \times 10^{-3} \mathrm{~m}, d j: 0.7831 \times 10^{-2} \mathrm{~m}, h: 2.5 \times 10^{-2}$ m)

\section{Comparison}

Figure 7 shows the variation of mass transfer coefficients with and without the presence of solids. Plot 'A' showed the data of the present study (density: 1200 $\mathrm{kg} / \mathrm{m}^{3}$ ). Plot 'B' gave the data on mass transfer coefficients in the absence of solids while plot ' $\mathrm{C}$ ' gave the data in the presence of high-density solids (density: $2320 \mathrm{~kg} / \mathrm{m}^{3}$ ). The plots showed that low-density solids (density: $1200 \mathrm{~kg} / \mathrm{m}^{3}$ ) as in the case of the present study gave improvements up to 3 folds over the coefficients obtained in the absence of solids. The plots also revealed that the coefficients with low density solids (density: $1200 \mathrm{~kg} / \mathrm{m}^{3}$ ) were found to be 200 times greater than those obtained with high density solids (density: $2320 \mathrm{~kg} / \mathrm{m}^{3}$ ). Solid-Fluid mixing appears to be more significant and severe with low-density solids, favoring a scouring action as well as hydrodynamic turbulence on the transfer surface resulting in higher coefficients.

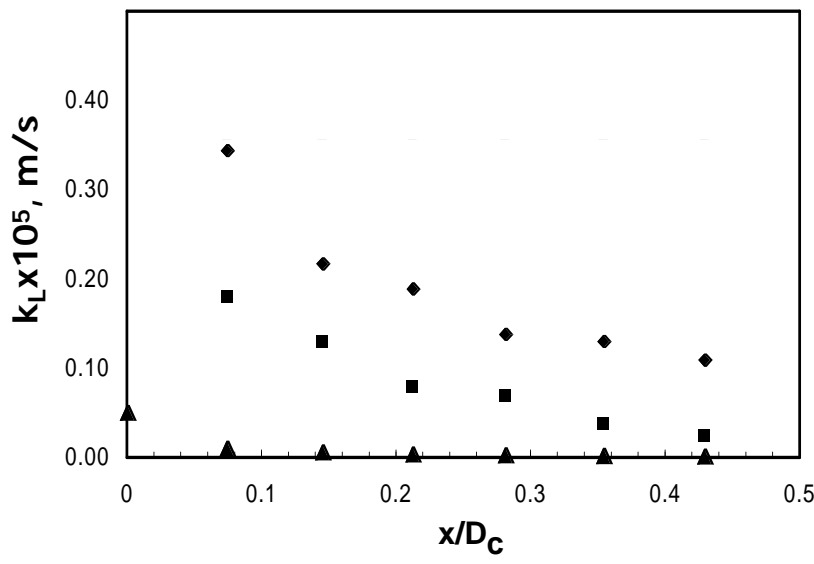

Figure 7. Comparison plots of present study (Pl ot ' $A$ ' density: $1200 \mathrm{~kg} / \mathrm{m}^{3}$ ) with the higher density solids (Plot ' $C$ ' density: 2320 $\mathrm{kg} / \mathrm{m}^{3}$ ) and without the presence of solids (Plot ' $B$ ') $\left(d_{p}: 5 \times 10^{-3} \mathrm{~m}, \chi: 0.01, h: 2.5 \times 10^{-}\right.$ $\left.{ }^{2} \mathrm{~m}, d j: 0.7831 \times 10^{-2} \mathrm{~m}, \quad Q: 8.75 \times 10^{-5}, \mathrm{~m}\right)$

Figure 8 shows the comparison of the coefficients obtained from the study on heat transfer data on turbulent submerged liquid jets of (Chang et al. 1995), single submerged jets in open containers of (Rao et al. 1971), free multi-jets data of Venkateswarlu and (Raju, 1979) with those obtained from the present data in the impingement region. The coefficient data of the present study (Coeuret, 1975) however are found to be higher than those obtained with turbulent submerged liquid jets (heat transfer), single submerged jets and free multi-jets.

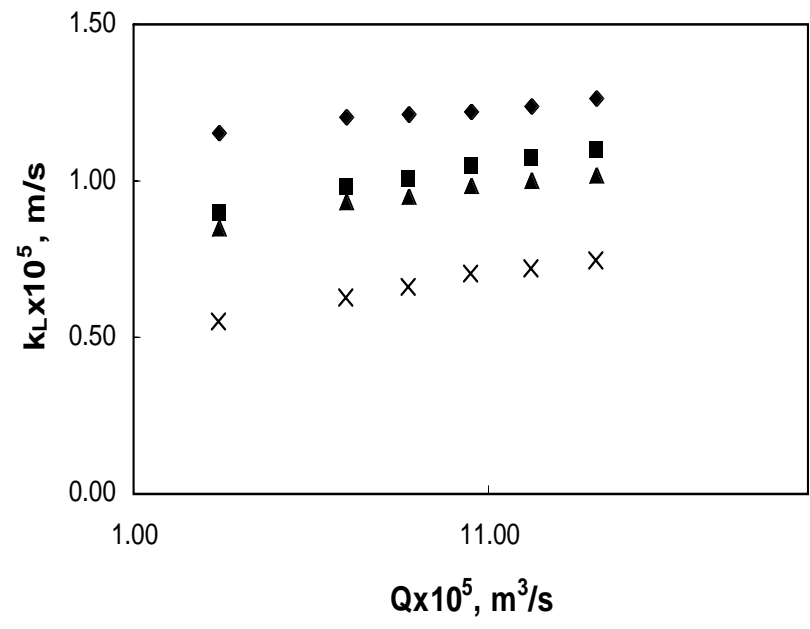

Figure 8. Comparison plots of present study with Chang et al. 1995 [turbulent subme rged single jets, heat transfer], Subba Rao et al. (1973) [Single Submerged jets in open container], Venkateswarlu and Raju (1979) [Free Multi-jets in open container] 


\section{Correlations Developed}

Earlier investigations (Gardon and Cobonpue, 1962; Gardon and Akfirat, 1965; Korger and Krizek, 1966; Subba Rao, et al. 1973; Chang et al. 1995) on heat and mass transfer in free and submerged impinging jets used conventional $N_{U} / J_{H}-R e$ or $S h / J_{D}-R e$ type of correlations. Similarly, the correlations are developed for mass transfer coefficient data, taking into account the effect of design and operating variables in the present study. The following format of the equations has been used to develop generalized correlations by the Regression analysis.

$$
J_{D}=C(N R e)^{n 1}\left(\phi_{1}\right)^{n 2}(\phi 2)^{n 3}(\chi)^{n 4}
$$

The data on reduction of ferri-cyanide ion in the impingement region yielded the following equations of correlation:

For the impingement region:

$$
\begin{aligned}
J_{D}= & 203.43\left(N_{R e}\right)^{-0.92}\left(h / D_{c}\right)^{-0.038}\left(d_{j} / D_{c}\right)^{1.06}(\chi)^{0.151} \\
& \text { for } \chi \leq 0.01
\end{aligned}
$$

$$
J_{D}=28.41\left(N_{R e}\right)^{-0.93}\left(h / D_{c}\right)^{-0.051}\left(d_{j} / D_{c}\right)^{1.07}(\chi)^{-0.312}
$$

for $\chi \geq 0.01$

For the decreasing coefficient region:

$J_{D}=7.10\left(N_{R e}\right)^{-0.96}\left(h / D_{c}\right)^{-0.042}\left(d_{j} / D_{c}\right)^{1.08}(\chi)^{0.057}\left(\chi / D_{c}\right)^{-0.804}$

for $\chi \leq 0.01$

$$
J_{D}=2.43\left(N_{R e}\right)^{-0.95}\left(h / D_{c}\right)^{-0.018}\left(d_{j} / D_{c}\right)^{1.08}(\chi)^{-0.18}\left(\chi / D_{c}\right)^{-0.814}
$$

for $\chi \geq 0.01$

The above equations are valid for the ranges of variables covered in the present study. The plots of the data correlated in accordance with the Eqs. 2 to 5 (Correlation factor versus flow Reynolds number) are shown in Figs. 9-12.

Correlation factor $(c f)=J_{D} /\left(\left(\phi_{1}\right)^{n 1}\left(\phi_{2}\right)^{\mathrm{n} 2}\left(\phi_{2}\right)^{\mathrm{n} 3}(\chi)^{n 4}\right)$

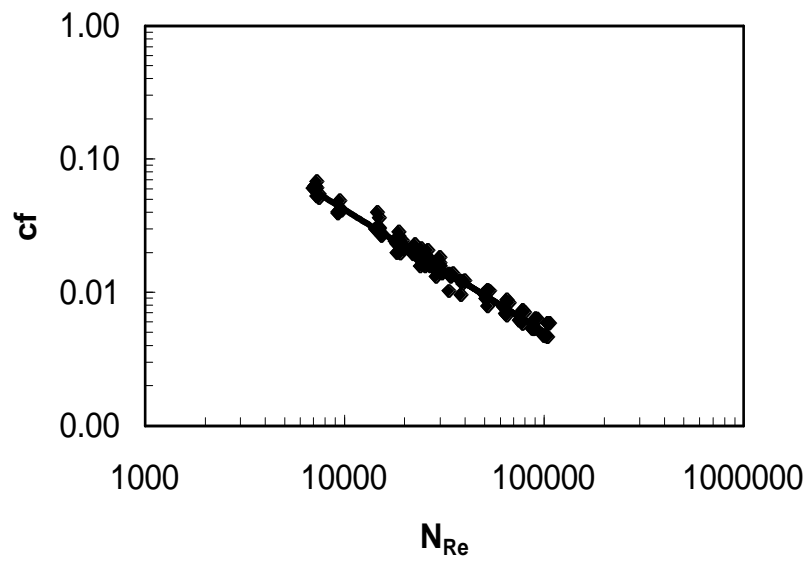

Figure 9. Correlation plot for impingement region for $\chi \leq 0.01$

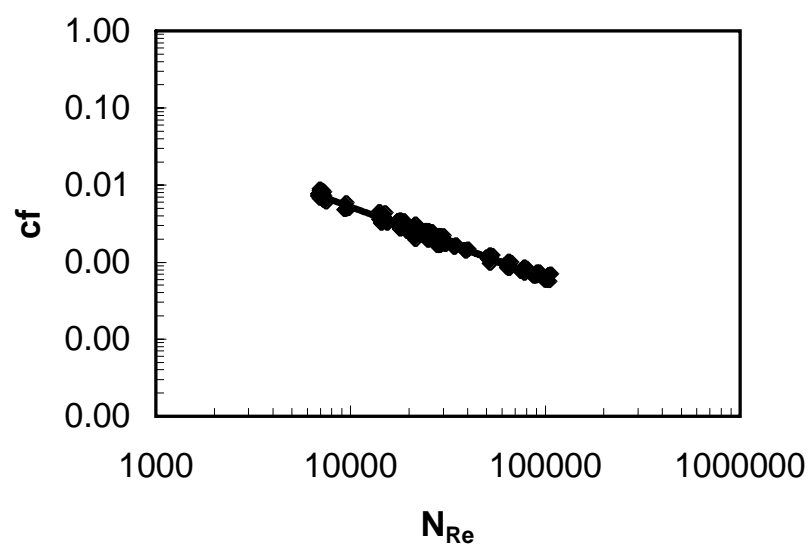

Figure 10. Correlation plot for impingement region for $\chi \geq 0.01$

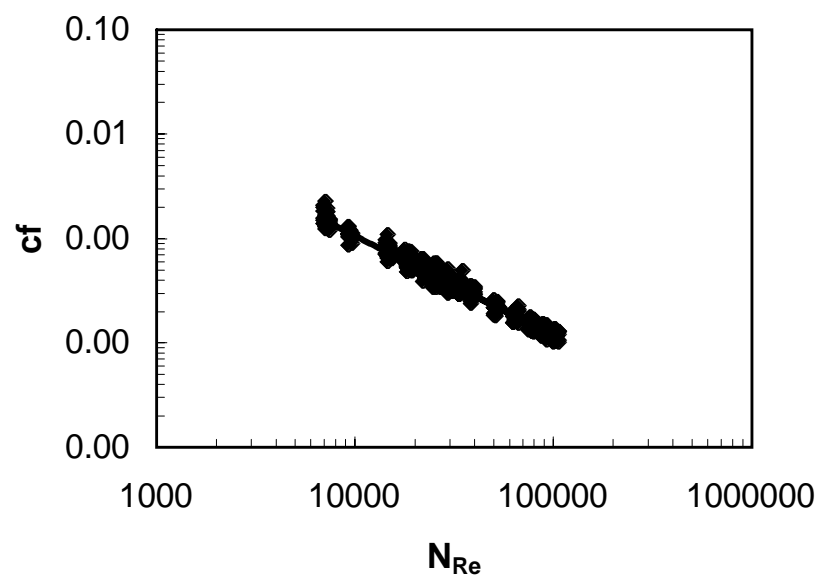

Figure 11. Correlation plot for decreasing coefficient region for $\chi \leq 0.01$ 


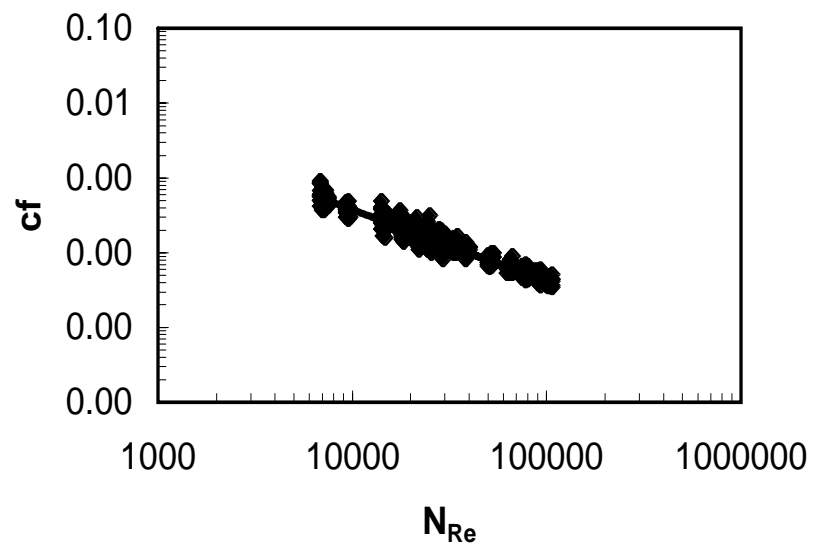

Figure 12. Correlation plot for decreasing coefficient region for $\chi \geq 0.01$

\section{Conclusions}

The correlations developed can be employed in the design of the electrochemical cell with submerged impinging jets in the presence of solids. The following inferences have been drawn from the results of the study:

(i) The mass transfer coefficients is found to increase with an increase in the flow rate both in impingement and decreasing coefficient regions as a result of an increase in turbulence at the target surface

(ii) The mass transfer coefficients is found to increase with an increase in the nozzle diameter at a given velocity in both the regions, due to large scale turbulence at a given velocity

(iii) The mass transfer coefficients showed a decrease in their value with the increase in the height of the nozzle from the target surface as the impact of jets did not fully reach the target surface due to local flow interactions. The decrease is found to be marginal in both the regions, and

(iv) The mass transfer coefficients initially showed an increase in value with the increase in solids fraction up to $1.0 \%$ and then decreased in both regions. It has been observed that at a lower solid fraction the scouring action together with the hydrodynamic turbulence increased the mass transfer coefficients marginally. At higher solid fraction, the effect of solids is found to decrease gradually resulting in lower coefficients.

\section{References}

Coeuret, F., 1975, "Transfert De Matierelors Del'impact Normal De Jets Liquides Circulaires Immerges," J. of
Chemical Engineering Science, Vol. 30, pp. 12571263.

Chin, D.T. and Tsang, C.H., 1978, "Mass Transfer to an Impinging Jet Electrode," J. of Electrochemical Society, Vol. 125(9), pp. 1461-1469.

Chang, C.T., Kojasoy, G. and Landis, F., 1995, "Confined Single- and Multiple-Jet Impingement Heat TransferI. Turbulent Submerged Liquid Jets," Int. J. of Heat and Mass Transfer, Vol. 38(5), pp. 833-842.

Gardon, R. and Cobonpue, J., 1962, "Heat Transfer Between a Flat Plate and Jets of Air Impinging on it," Int. Developments in Heat transfer, ASME, New York, pp. 454-460.

Gardon, R. and Akfirat, J.C., 1965, "The Role of Turbulence in Determining the Heat Transfer Characteristics of Impinging Jets," Int. J. of Heat and Mass Transfer, Vol. 8, pp. 1261-1272.

Korger, M. and Krizek, F., 1966, "Mass Transfer Coefficient in Impingement Flow from Slotted Nozzles," Int. J. of Heat and Mass Transfer, Vol. 91, pp. 337-344.

Kendoush, A.A., 1998, "Theory of Stagnation Region Heat and Mass Transfer to Fluid Jets Impinging Normally on Solid Surfaces," Chemical Engineering and Processing, Vol. 37, pp. 223-238.

Lin, C.S., Denton, E.B., Gaskill, H.S. and Putnam, G.L., 1951, "Diffusion Controlled Electrode Reactions," Industrial and Engineering Chemistry, Vol. 43(9), pp. 2136-2143.

Lee, D.H., Lee, Y.M., Kim, Y.T., Won, S.Y. and Chung, Y.S., 2002, "Heat Transfer Enhancement by Perforated Plate Installed Between an Impinging Jet and the Target Plate," Int. J. of Heat and Mass Transfer, Vol. 45, pp. 213-217.

Sakakihara, Y., Flora, J.R.V., Suidan, M.T. and Kuroda, M., 1994, "Measurement of Mass Transfer Coefficients with an Electrochemical Method using Dilute Electrolyte Solutions," J. of Water Research, Vol. 28(1), pp. 9-16.

Subba Rao, B., Krishna, M.S. and Jagannadha Raju, G.J.V., 1973, "Ionic Mass Transfer with Submerged Jets-I," Periodica Polytecnica Chemical Engineering, Vol. 17(2), pp. 185-195.

Travnicek, Z. and Tesar, V., 2003, "Annular Synthetic Jet used for Impinging Flow Mass Transfer," Int. J. of Heat and Mass Transfer, Vol. 46, pp.3291-3297.

Venkateshwarlu, P. and Jagannadha Raju, G.J.V., 1979, "Ionic Mass Transfer with Imping Multi-Jets, Indian J. Technol, Vol. 17(1), pp. 1-4. 